\title{
Boronic acid derivatives targeting HIV-1
}

\author{
X. Chen ${ }^{1}$, K. Bastow ${ }^{2}$, B. Goz ${ }^{3}$, L. Kucera ${ }^{4}$, \\ S.L. Morris-Natschke ${ }^{2}$ and K.S. Ishaq ${ }^{2, *}$ \\ ${ }^{1}$ Department of Chemistry, University of Georgia, Athens, \\ GA 30602. \\ ${ }^{2}$ Division of Medicinal Chemistry and Natural Products, \\ School of Pharmacy, University of North Carolina, \\ Chapel Hill, NC 27599. \\ ${ }^{3}$ Department of Pharmacology, School of Medicine, \\ University of North Carolina, Chapel Hill, NC 27599, \\ ${ }^{4}$ Department of Microbiology and Immunology, \\ Bowman Gray School of Medicine of Wake Forest \\ University, Winston-Salem, NC 27157.
}

\section{Summary}

A series of novel boronic acid derivatives containing either a pyrimidine or purine base was synthesized. The preparation involved the condensation of 4-bromobutyl boronic acid with the appropriate base. These acyclic nucleosides were designed as potential antiviral agents especially targeting the human immunodeficiency virus. Two analogues, 6-chloro-9(4-dihydroxyborylbutyl)purine and 2,6-dichloro-9-(4dihydroxyborylbutyl)purine, exhibited $\mathrm{EC}_{50}$ values of $7.7 \mu \mathrm{M}$ and $0.99 \mu \mathrm{M}$, respectively, in an HIV-1 syncytial plaque reduction assay.

Key-words: antiviral; boronic acid; HIV-1; nucleoside analogues.

\section{Introduction}

A large number and variety of nucleoside analogues have been synthesized as potential antiviral and antitumour agents. Some of these compounds are currently in clinical trials, and others are now being used as chemotherapeutic agents. In general, nucleoside analogues have been designed as antimetabolites through isosteric substitution or through modification of the sugar moiety. The former strategy led to compounds such as 5-iodo-2'-deoxyuridine and 5-fluorouracil, while the latter modification resulted in the discovery of azidothymidine (AZT) and cytosine arabinoside. Furthermore, the design of aciclovir as an acyclic analogue of guanosine, (Schaeffer et al.,

Received 12 July, 1995; revised 15 September, 1995; accepted 18 September, 1995. *For correspondence. Tel. 919 926-0065; Fax 919966 6919.
1978) and its success as an antiherpes agent, have led to the preparation of a variety of other acyclic analogues as potential antiviral agents (Harden et al., 1987; Vandendriessche et al., 1992; Barnard et al., 1993).

Accordingly, the synthesis of a series of acyclic nucleosides containing the boronic acid functionality as potential antiviral agents was embarked upon. The studies were also extended to investigate the potential antitumour activity of these compounds and, thus, demonstrate the versatility of the boronic acid moiety. This series of compounds will serve as a model for further structure-activity relationship (SAR) studies.

Interest in the boronic acid group stems from the fact that this functionality has been incorporated into many diverse structures, which has resulted in a range of biological activities. For example, compounds having inhibitory activity against serine proteases (Philip and Bender 1971), chromatin bound protease (Carter et al., 1977), and dihydroorotase (Kinder et al., 1990) have been prepared. In addition, boronic acid derivatives have inhibited cell replication (Goz et al., 1986). Other investigators (Schinazi and Prusoff 1985) have introduced the boronic acid functionality into the 5- and 6-positions of pyrimidine as potential antiviral and antitumour agents. Furthermore, boron-containing compounds have been designed as candidates for boron neutron capture therapy (Lesnikowski et al., 1993).

Further rationale for the incorporation of boronic acid into nucleoside analogues is the close relationship of boron and carbon (Schinazi and Prusoff 1985). The two hydroxy groups of a boronic acid may behave as alcoholic hydroxy groups and be preferentially phosphorylated by thymidine kinase in a similar manner to the hydroxy group of aciclovir.

\section{Results \\ Chemistry}

The first step in the synthesis of the candidate boronic acid derivatives is the preparation of 4-bromobutyl boronic acid (1). This was accomplished according to the procedure of Brown et al. (1971). 4-Bromo-1-butene was reacted with an excess of catecholborane under nitrogen. After removal of the unreacted catecholborane under vacuum, water was added to decompose the 2-(4-bromobutyl)-1,3,2-benzodioxaborole and give the desired product (1) in $78 \%$ yield (Fig. 1). 4-Bromobutyl boronic 
acid (1) was then reacted with the appropriate pyrimidine or purine base utilizing the procedures of Lee et al., (1977) and Harden et al., (1987). Thus, thymine was first reacted with potassium carbonate, after which 4-bromobutyl boronic acid was added to give 1-(4-dihydroxyborylbutyl)thymine (2) in $44 \%$ yield (Fig. 2). In the synthesis of 6-chloro-9-(4-dihydroxyborylbutyl)purine (3), sodium hydride was reacted with 6 -chloropurine and the resultant anion was then reacted with 1 to give the desired product (3) in $51 \%$ yield (Fig. 3). As with the other purine bases, the $\mathrm{N}^{9}$-isomer was the desired and major product, and was purified by silica gel chromatography. With the exception of 6-chloropurine, all other purine bases were reacted with $\mathrm{K}_{2} \mathrm{CO}_{3}$ by a procedure analogous to that used for compound 2 and depicted in Fig. 2. In this manner, the 2-amino-6-chloropurine analogue 4 was prepared in a $56 \%$ yield. Compound 5, 9-(4dihydroxyborylbutyl)guanine, was synthesized in an $81 \%$ yield by refluxing compound 4 in $2 \mathrm{~N} \mathrm{HCl}$ then neutralizing the acidic reaction mixture (Harden et al., 1987) (Fig. 4). The latter procedure was also used in the synthesis of compound 6, 9-(4-dihydroxyborylbutyl)hypoxanthine from compound 3 ( $82 \%$ yield). The 2,6-dichloro analogue 7 of compound 3 was prepared in a $48 \%$ yield in the same manner described for compound 2 . Compound 8, 6-chloro-9-[4-(1,3-propyldioxaborylbutyl)]purine was obtained in a $74 \%$ yield by reacting 1,3-propanediol with compound 3 (Goralski et al., 1987) (Fig. 5).

\section{Conformational analysis}

Systematic conformational searches of $\mathbf{5}$ and aciclovir were performed with Sybyl 6.0 by using new molecular mechanics force field parameters for the boronic acid moiety (Chen et al., 1994). Since there are five rotatable bonds in each side chain, both of these compounds are very flexible conformationally. There are 10 conformations that have very similar potential energy for both compounds; the difference is within $1 \mathrm{kcal} \mathrm{mole}{ }^{-1}$. Thus, at $24^{\circ} \mathrm{C}$, all of these conformations are easily accessible. The systematic searches indicated that the potential energy surfaces for both compounds were very similar. The lowest potential energy conformations for both aciclovir and $\mathbf{5}$ were further geometry optimized by using the AM1 semi-empirical method. The resulting geometries are shown in Fig. 6.

\section{Antiviral and other activities}

The boronic acid derivatives (2-8) were screened for their cell cytotoxicity and anti-HIV-1 activity by utilizing ${ }^{3} \mathrm{H}-\mathrm{TdR}$ incorporation into total DNA and an HIV plaque reduction assay (Kucera et al., 1990). In this series, only two compounds ( 3 and 7 ) showed appreciable in-vitro activity. The
$I C_{50}$ and $E_{50}$ values of 3 for cytotoxicity and anti-HIV activity were 43 and $7.7 \mu \mathrm{M}$, respectively, while those of 7 were 4.9 and $0.99 \mu \mathrm{M}$, respectively (Table 1). Compounds $2,4,5,6$ and 8 had no detectable toxicity or antiHIV activity. In addition, the two most potent compounds in this series ( 3 and 7 ), were screened against the SV-28 tumour cell line (Crumpton et al., 1988). These com- . pounds ( 3 and 7 ) had $1 \mathrm{C}_{50}$ values of $60 \mu \mathrm{M}$ and $4 \mu \mathrm{M}$, respectively, in this assay.

The boronic acid derivative 5 , a close conformational analogue of aciclovir, was tested for anti-herpes activity in a plaque reduction assay using Vero cells (Bastow et al., 1983). Its $\mathrm{EC}_{50}$ value was $110 \mu \mathrm{M}$. As compound 5 was not growth inhibitory at concentrations up to $200 \mu \mathrm{M}$ against Vero cells, it exhibited selective but weak antiherpes activity.

\section{Viral thymidine kinase (TK)}

$\mathrm{TK}^{+}$(ATCC CRL1802) and TK ${ }^{-}$(LM cells) are two transformed cell lines that lack cellular thymidine kinase activity. However, the former has been stably transfected with the herpes simplex virus thymidine kinase, while the latter has not. These cell lines were used in order to try to determine whether either of the hydroxy groups of the boronic acid functionality in 5 is phosphorylated in intact cells by thymidine kinase. Aciclovir was included in the assay as a positive control, and it showed distinctly different potencies in the two cell lines. The $I_{50}$ values of aciclovir against the $\mathrm{LM} \mathrm{TK}^{+}$and the $\mathrm{LM} \mathrm{TK}^{-}$cells were $4.4 \mu \mathrm{M}$ and $220 \mu \mathrm{M}$, respectively. Compound 5 did not show cytotoxicity against either cell line at concentrations up to $150 \mu \mathrm{M}$.

\section{Discussion}

A series of novel compounds (2-8) was designed as antiviral agents especially targeting the human immunodeficiency virus. These analogues contain either a pyrimidine ring system as in 2 or a purine ring system as in 3-8 to which is attached a four carbon chain bearing a boronic acid functionality.

Compound 2 contains thymine, the same pyrimidine base found in $A Z T$ and $2^{\prime}, 3^{\prime}$-didehydro- $2^{\prime}, 3^{\prime}$-dideoxythymidine (d4T), but, unlike $A Z T$ and $d 4 T$, has an acyclic side chain. This compound (2) exhibited moderate anti-HIV-1 activity (Table 1).

Among the purine series (3-8), only compounds 3 and 7 showed appreciable activity against HIV-1, while compounds 4-6 and 8 were inactive (Table 1). The rationale for the synthesis of 3 was based on its facile conversion to the hypoxanthine analogue (6) and its decreased polarity compared with analogues 4-6. Thus, the lack of activity of the latter compounds may be due either to their polar 
$110 X$. Chen et al.

$\overbrace{\mathrm{Br}}+\mathrm{N}_{\mathrm{O}^{\prime}}^{\mathrm{B}-\mathrm{H}} \stackrel{\mathrm{Neat}}{{ }_{95^{\circ} \mathrm{C}}}$

$\stackrel{\mathrm{H}_{2} \mathrm{O}}{\longrightarrow}$ PO $_{1}^{\mathrm{BO}}$
Fig. 1. Synthesis of 4-bromobutyl boronic acid (1).
Fig. 2. Synthesis of 1-(4-dihydroxyborylbutyl) thymine (2).
$\left.\right|_{N} ^{C l}$<smiles>O=C[O+]</smiles><smiles>BrCCCC[Pb]</smiles>

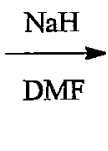<smiles>[18OH]CCCCn1cnc2c(Cl)ncnc21</smiles>

3
Fig. 3. Synthesis of 6-chloro-9-(4dihydroxyborylbutyl)purine (3).<smiles>Nc1nc(Cl)c2ncn(CCCC[R]OCCO)c2n1</smiles>

4

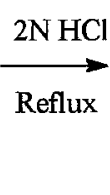

(HO)<smiles>Nc1nc2c(ncn2CCCC[PH2+]O)c(=O)[nH]1</smiles>

5<smiles>OCCCCCn1cnc2c(Cl)ncnc21</smiles>

3<smiles>Cc1ncnc2c1ncn2CCCCB1OCCCO1</smiles>

Fig. 5. Synthesis of 6-chloro-9-[4-(1,3propyldioxaborylbutyl)]purine (8). 


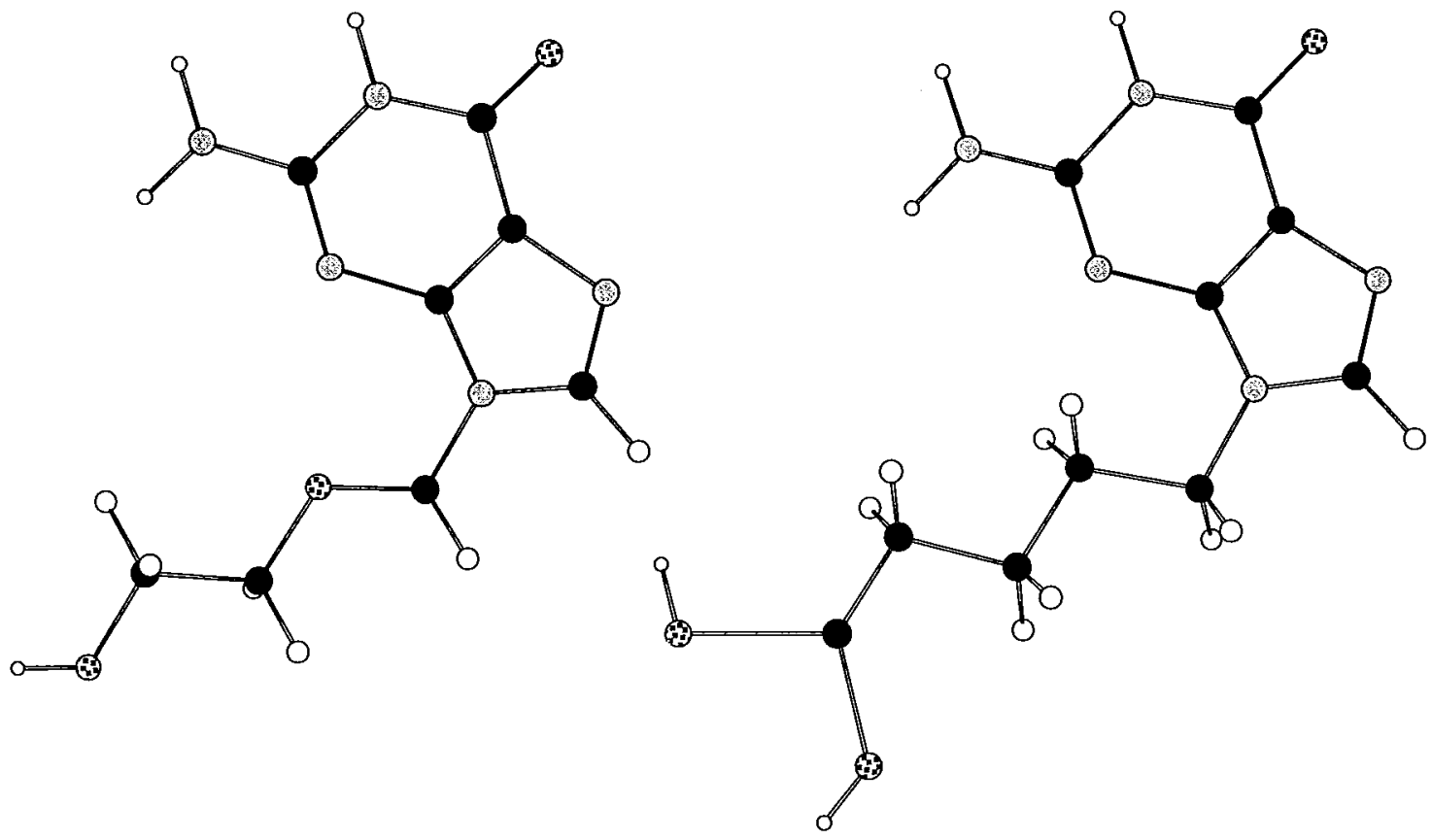

Fig. 6. Global minimum conformations of aciclovir (left) and compound 5 (right).<smiles>Cc1cn(CCCCBr)c(=O)[nH]c1=O</smiles>

Structure A<smiles>[B]CCCCn1cnc2c(P)nc(C)nc21</smiles>

Structure $\mathrm{B}$<smiles>[R9]c1nc2c(ncn2CCCCBr)c(=O)[nH]1</smiles>

Structure $\mathrm{C}$
Table 1. Cyiotoxicity and antiviral activity of compounds (2-8).

\begin{tabular}{|c|c|c|c|c|c|c|}
\hline Cmpd & Structure & $R_{1}$ & $\mathrm{R}_{2}$ & $\mathrm{R}_{3}$ & $\begin{array}{l}\mathrm{IC}_{50} \text { for CEM-SS cell } \\
\text { toxicity assay }\end{array}$ & $\begin{array}{l}\mathrm{EC}_{50} \text { for anti-HIV } \\
\text { plaque reduction assay }\end{array}$ \\
\hline 2 & A & $\mathrm{B}(\mathrm{OH})_{2}$ & - & - & no inhibition @ $100 \mu \mathrm{M}$ & $82 \mu \mathrm{M}$ \\
\hline 3 & B & $\mathrm{B}(\mathrm{OH})_{2}$ & $\mathrm{Cl}$ & $H$ & $43 \pm 31.1 \mu \mathrm{M}$ & $7.7 \pm 1.5 \mu \mathrm{M}$ \\
\hline 4 & B & $\mathrm{B}(\mathrm{OH})_{2}$ & $\mathrm{Cl}$ & $\mathrm{NH}_{2}$ & no inhibition $@ 100 \mu \mathrm{M}$ & no activity @ $100 \mu \mathrm{M}$ \\
\hline 5 & C & $\mathrm{B}(\mathrm{OH})_{2}$ & - & $\mathrm{NH}_{2}$ & no inhibition@100 $\mu \mathrm{M}$ & no activity@100 $\mu \mathrm{M}$ \\
\hline 6 & $\mathrm{C}$ & $\mathrm{B}(\mathrm{OH})_{2}$ & - & $H$ & no inhibition @ $100 \mu \mathrm{M}$ & no activity @ $100 \mu \mathrm{M}$ \\
\hline 7 & $\mathrm{~B}$ & $\mathrm{~B}(\mathrm{OH})_{2}$ & Cl & C1 & $4.9 \pm 2.2 \mu \mathrm{M}$ & $0.99 \pm 0.01 \mu \mathrm{M}$ \\
\hline 8 & B & & $\mathrm{Cl}$ & $\mathrm{H}$ & no inhibition@100 $\mu \mathrm{M}$ & no activity@100 $\mu \mathrm{M}$ \\
\hline
\end{tabular}

To measure cytotoxicity, serial concentrations of test compound were added to exponentially growing CEM-SS cells. After $48 \mathrm{hrs}$ incubation, the cells were pulse labeled with $\left[\mathrm{H}^{3}\right] \mathrm{TdR}$ for 6 hrs to measure total DNA synthesis in treated and untreated cell cultures and calculate the $\mathrm{IC}_{50}$ as previously described (Kucera et al., 1990). The $\mathrm{IC}_{50}$ value for AZT, the control antiviral compound, was $5.1 \pm 3.0 \mu \mathrm{M}$ as previously reported (Piantadosi et al., 1991).

To measure anti-HIV-1 activity, CEM-SS cell monolayers were infected with HIV-1 and overlaid with RPMI-1640 medium containing serial concentrations of test compound. After 5 days incubation, the numbers of HIV-1 syncytial plaques in treated and untreated cell monolayers were counted to calculate the $\mathrm{EC}_{50}$ as previously described (Kucera et al., 1990). The $\mathrm{EC}_{50}$ value for $\mathrm{AZT}$, the control antiviral compound, was $0.004 \pm 0.002 \mu \mathrm{M}$ as previously reported (Piantadosi et al., 1991). 
character or to structural features that may interfere with interaction with a putative target site. If lipophilicity is a factor in the increased anti-HIV activity of 3 , a further increase in lipophilicity might result in improvement of activity. Accordingly, two strategies were devised to improve on the lipophilic character of 3 . One involved the introduction of an additional chloro group into the purine ring system as in compound 7 ; the other involved the conversion of $\mathbf{3}$ to its prodrug $\mathbf{8}$, where the boronic acid functionality was converted to its 1,3-propyldioxaboryl derivative.

Compound 7, 2,6-dichloro-9-(4-dihydroxyborylbutyl)purine, exhibited more potent anti-HIV activity and increased cytotoxicity compared with the mono-chloro analogue 3. However, the prodrug 8 lost activity, which suggests that the borate ester functionality may not be easily hydrolysed intracellularly, and that the boronic acid functionality is essential for activity.

Since compound $\mathbf{5}$ is a close conformational analogue of aciclovir, as determined by conformational analyses with Sybyl (Fig. 6), it was of interest to determine whether either of the hydroxy groups of the boronic acid functionality in $\mathbf{5}$ could be phosphorylated by TK as is the hydroxy group of aciclovir. The $\mathrm{IC}_{50}$ of aciclovir in $\mathrm{LM} \mathrm{TK}^{+}$cells was lower than its $\mathrm{IC}_{50}$ in $\mathrm{LM} \mathrm{TK}^{-}$cells as expected (see results); however, compound $\mathbf{5}$ showed no cytotoxicity against either cell line at concentrations up to $150 \mu \mathrm{M}$. Thus, it was not possible to ascertain if phosphorylation of $\mathbf{5}$ was required for cytotoxicity. Several possibilities could account for these data. Compound 5 may not be a substrate for herpes TK but is a substrate for a cellular TK, since 5 did have some cytotoxicity for SV-28 cells $\left(I C_{50}=86 \mu \mathrm{M}\right)$, which have a cellular TK. The weak activity of 5 also may be due to poor penetration into the cell rather than an inability to act as a substrate for herpes TK. Finally, the boronic acid derivatives may not require TK for activation. The boronic acid derivatives could be similar to acyclic nucleoside phosphonates; where the latter compounds, acting as analogues of nucleoside monophosphates, bypass the phosphorylation step by TK (De Clercq, 1995).

Further modifications to maximize activity and reduce toxicity are in progress.

\section{Materials and Experimental Procedures: Chemistry}

Melting points were recorded on a Thomas Hoover melting point apparatus and are uncorrected. ${ }^{1} \mathrm{H}$ NMR spectra were obtained using a Bruker AC-300 spectrometer. Elemental analyses were performed by Atlantic Microlab Inc., Norcross, GA. Some boronic acid analogues did not give a correct elemental analysis even though they were pure by NMR and by TLC in different systems. These compounds were analysed by using electrospray mass spectroscopy (ESMS). Purity was also ascertained by high pressure liquid chromatography
(HPLC) with a $\mathrm{C}_{18}$ silica column (Whatman $\mathrm{C}_{18} 5 \mu \mathrm{M}$ particles) and a linear gradient of $15 \mathrm{mM}$ triethylammonium phosphate (TEAP) (pH 3) to $100 \% \mathrm{CH}_{3} \mathrm{CN}$. Absorbance of eluent was monitored at $260 \mathrm{~nm}$. Thin layer chromatography (TLC) was performed on $1 \times 3$ inch fluorescent precoated Whatman silica gel 60 TLC plates. The TLC plates were visualized by UV light, iodine vapor, or charring following sulphuric acid spray. Silica gel (70-230 mesh) from Fisher Scientific was used for column chromatography. Reagents were purchased from Aldrich Chemical Co., Inc. Solvents, including $\mathrm{CH}_{3} \mathrm{CN}$, dimethyiformamide (DMF), $\mathrm{CH}_{2} \mathrm{Cl}_{2}$, and tetrahydrofuran (THF), were dried by placement over molecular sieves $(4 \AA$ ) for 2 weeks before use.

\section{4-Bromobutyl boronic acid 1}

4-Bromo-1-butene $(5.4 \mathrm{~g}, 40 \mathrm{mmol})$ was added to catecholborane $(5.76 \mathrm{~g}, 48 \mathrm{mmol})$. The reaction mixture was stirred under nitrogen and heated to $95{ }^{\circ} \mathrm{C}$ for $4 \mathrm{~h}$. The unreacted starting material was distilled under high vacuum. $(1 \mathrm{~mm} \mathrm{Hg})$ at room temperature. Water $(70 \mathrm{ml})$ was added to the slightly yellow liquid residue and stirred for $2 \mathrm{~h}$. The white solid was filtered and recrystallized from $\mathrm{CHCl}_{3}$. Crystals $(5.6 \mathrm{~g}, 78 \%$ yield) were obtained, which were used directly in the next step. mp 81-83 ${ }^{\circ} \mathrm{C} ;{ }^{1} \mathrm{H}$ NMR (DMSO-d $\left.\mathrm{d}_{6}\right) \delta 0.63\left(\mathrm{t}, 2 \mathrm{H}, \mathrm{BCH}_{2}\right), 1.40-1.52$ (m, 2H, $\left.\mathrm{BCH}_{2} \mathrm{CH}_{2}\right), 1.61-1.85\left(\mathrm{~m}, 2 \mathrm{H}, \mathrm{CH}_{2} \mathrm{CH}_{2} \mathrm{Br}\right), 3.53(\mathrm{t}, 2 \mathrm{H}$, $\left.\mathrm{CH}_{2} \mathrm{CH}_{2} \mathrm{Br}\right), 7.45\left[\mathrm{~s}, 2 \mathrm{H}, \mathrm{B}-(\mathrm{OH})_{2}\right]$.

\section{1-(4-Dihydroxyborylbutyl)thymine 2}

Potassium carbonate $(0.6 \mathrm{~g}, 4.4 \mathrm{mmol})$ was added to a solution of thymine ( $0.56 \mathrm{~g}, 4.4 \mathrm{mmol})$ in DMF $(15 \mathrm{ml})$ and stirred for 30 $\mathrm{min}$. To this reaction mixture, 4-bromobutyl boronic acid $(0.4 \mathrm{~g}$, $2.2 \mathrm{mmol}$ ) dissolved in DMF $(5 \mathrm{ml})$ was added dropwise, and stirring was continued for 2 days at room temperature. After the $\mathrm{K}_{2} \mathrm{CO}_{3}$ was filtered, the DMF was evaporated under high vacuum. The residue was purified on a silica gel column eluting with a discontinuous gradient of $\mathrm{CHCl}_{3} / \mathrm{MeOH}(95: 5,85: 15)$. The appropriate TLC-homogenous fractions were pooled and evaporated to give $0.22 \mathrm{~g}$ (44\% yield) of pure product. $\mathrm{mp}$ 130-132 ${ }^{\circ} \mathrm{C}$; ${ }^{1} \mathrm{H}$ NMR (DMSO-d $)_{6} \delta 0.62\left(\mathrm{t}, 2 \mathrm{H}, \mathrm{BCH}_{2}\right.$ ), 1.22-1.35 (m, 2H, BCH$\left.{ }_{2} \mathrm{CH}_{2}\right), 1.42-1.60\left(\mathrm{~m}, 2 \mathrm{H}, \mathrm{CH}_{2} \mathrm{CH}_{2} \mathrm{~N}\right)$, 1.75 (s, 3H, $\mathrm{CH}_{3}-\mathrm{C} 5$ thymine), $3.58\left(\mathrm{t}, 2 \mathrm{H}, \mathrm{CH}_{2} \mathrm{CH}_{2} \mathrm{~N}\right), 7.42[\mathrm{~s}$, $\left.2 \mathrm{H}, \mathrm{B}-(\mathrm{OH})_{2}\right], 7.50(\mathrm{~s}, 1 \mathrm{H}, \mathrm{H}-\mathrm{C} 6$ thymine $), 11.15(\mathrm{~s}, 1 \mathrm{H}, \mathrm{NH}$ thymine). Anal. $\left(\mathrm{C}_{9} \mathrm{H}_{15} \mathrm{O}_{4} \mathrm{~N}_{2} \mathrm{~B}\right)$ calcd. C 47.82, $\mathrm{H} 6.69, \mathrm{~N} 12.40$; found $\mathrm{C} 47.71, \mathrm{H} 6.72, \mathrm{~N} 12.35$.

\section{6-Chloro-9-(4-dihydroxyborylbutyl)purine 3}

Sodium hydride $(0.22 \mathrm{~g}, 7.2 \mathrm{mmol})$ was added to 6 -chloropurine $(0.93 \mathrm{~g}, 6.0 \mathrm{mmol})$ in DMF $(20 \mathrm{ml})$ and stirred for $10 \mathrm{~min}$. 4-Bromobutyl boronic acid $(1.1 \mathrm{~g}, 6.0 \mathrm{mmol})$ in DMF $(5 \mathrm{ml})$ was added to the reaction mixture and stirred at room temperature for $16 \mathrm{~h}$. After the removal of DMF under high vacuum, the residue was purified by column chromatography $\left(\mathrm{CHCl}_{3} / \mathrm{MeOH}\right.$ discontinuous gradient $95: 5,9: 1)$ to yield $0.78 \mathrm{~g}$ (51\% yield) of pure product. mp $135-138^{\circ} \mathrm{C}$; ${ }^{1} \mathrm{H}$ NMR (DMSO-d $\left.\mathrm{d}_{6}\right) \delta 0.62(\mathrm{t}$, $\left.2 \mathrm{H}, \mathrm{BCH}_{2}\right), 1.22-1.35\left(\mathrm{~m}, 2 \mathrm{H}, \mathrm{BCH}_{2} \mathrm{CH}_{2}\right), 1.78-1.91(\mathrm{~m}, 2 \mathrm{H}$, $\left.\mathrm{CH}_{2} \mathrm{CH}_{2} \mathrm{~N}\right), 4.29\left(\mathrm{t}, 2 \mathrm{H}, \mathrm{CH}_{2} \mathrm{CH}_{2} \mathrm{~N}\right), 7.41\left[\mathrm{~s}, 2 \mathrm{H}, \mathrm{B}-(\mathrm{OH})_{2}\right], 8.69$ 
(s, $1 \mathrm{H}, \mathrm{H}-\mathrm{C} 8$ purine), $8.81(\mathrm{~s}, 1 \mathrm{H}, \mathrm{H}-\mathrm{C} 2$ purine). Anal. $\left(\mathrm{C}_{9} \mathrm{H}_{12} \mathrm{O}_{2} \mathrm{~N}_{4} \mathrm{BCl}\right)$ calcd. $\mathrm{C} 42.47, \mathrm{H} 4.75, \mathrm{~N} \mathrm{22.02}$; found $\mathrm{C}$ $42.48, \mathrm{H} 4.80, \mathrm{~N} 22.06$.

\section{2-Amino-6-chloro-9-(4-dihydroxyborylbutyl)purine 4}

This analogue was synthesized in a similar manner as compound 2 with 2-amino-6-chloropurine ( $1.36 \mathrm{~g}, 8 \mathrm{mmol}$ ), 4-bromobutyl boronic acid $(1.45 \mathrm{~g}, 8 \mathrm{mmol})$, and $\mathrm{K}_{2} \mathrm{CO}_{3}(1.66 \mathrm{~g}$, $12 \mathrm{mmol}$ ) in DMF (20 mL). Wgt, $1.2 \mathrm{~g}, 56 \%$ Yield $\mathrm{mp}$ $154-156^{\circ} \mathrm{C} ;{ }^{1} \mathrm{H}$ NMR (DMSO-d $\left.{ }_{6}\right) \delta 0.62\left(\mathrm{t}, 2 \mathrm{H}, \mathrm{BCH}_{2}\right.$ ), 1.20-1.32 (m, 2H, BCH $\left.\mathrm{CH}_{2}\right), 1.68-1.77\left(\mathrm{~m}, 2 \mathrm{H}, \mathrm{CH}_{2} \mathrm{CH}_{2} \mathrm{~N}\right)$, 4.04 (t, 2H, $\mathrm{CH}_{2} \mathrm{CH}_{2} \mathrm{~N}$ ), $6.89\left(\mathrm{~s}, 2 \mathrm{H}, \mathrm{NH}_{2}-\mathrm{C} 2\right.$ purine), 7.41 [s, $\left.2 \mathrm{H}, \mathrm{B}-(\mathrm{OH})_{2}\right], 8.11(\mathrm{~s}, 1 \mathrm{H}, \mathrm{H}-\mathrm{C} 8$ purine). ESMS calcd. for $\mathrm{C}_{9} \mathrm{H}_{13} \mathrm{O}_{2} \mathrm{~N}_{5} \mathrm{BCl} 270.09[\mathrm{MH}]^{+}$, found 270.10 .

\section{9-(4-Dihydroxyborylbutyl)guanine 5}

Compound $4(0.5 \mathrm{~g}, 1.85 \mathrm{mmol})$ was added to aqueous $\mathrm{HCl}$ $(5 \mathrm{ml}, 2 \mathrm{~N})$, and the reaction mixture was heated to reflux for $5 \mathrm{~h}$. After cooling to room temperature, aqueous $\mathrm{NaOH}(10 \%)$ was added to neutralize the reaction mixture to $\mathrm{pH} 7$. Water was evaporated under high vacuum, and $\mathrm{MeOH}$ was added to the residue to remove the unreacted starting material. The remaining solid was washed with water $(3 \times 20 \mathrm{ml})$ then stirred in water overnight. After filtration, the product was air dried for 2 days. Wt. $0.38 \mathrm{~g}, 81 \%$ Yield. $\mathrm{mp} 202-205^{\circ} \mathrm{C} ;{ }^{1} \mathrm{H}$ NMR (DMSO$\left.\mathrm{d}_{6}\right) \delta 0.62\left(\mathrm{t}, 2 \mathrm{H}, \mathrm{BCH}_{2}\right), 1.20-1.32\left(\mathrm{~m}, 2 \mathrm{H}, \mathrm{BCH}_{2} \mathrm{CH}_{2}\right)$, 1.62-1.75 (m, 2H, $\left.\mathrm{CH}_{2} \mathrm{CH}_{2} \mathrm{~N}\right), 3.93\left(\mathrm{t}, 2 \mathrm{H}, \mathrm{CH}_{2} \mathrm{CH}_{2} \mathrm{~N}\right), 6.42(\mathrm{~s}$, $2 \mathrm{H}, \mathrm{NH}_{2}-\mathrm{C} 2$ guanine), $7.43\left[\mathrm{~s}, 2 \mathrm{H}, \mathrm{B}-(\mathrm{OH})_{2}\right], 7.70(\mathrm{~s}, 1 \mathrm{H}, \mathrm{H}-\mathrm{C} 8$ guanine), $10.50(\mathrm{~s}, 1 \mathrm{H}, \mathrm{H}-\mathrm{N} 3$ guanine). ESMS calcd. for $\mathrm{C}_{9} \mathrm{H}_{14} \mathrm{O}_{3} \mathrm{~N}_{5} \mathrm{~B}$ 252.12 [MH] $]^{+}$, found 252.10.

\section{9-(4-Dihydroxyborylbutyl)hypoxanthine 6}

This analogue was synthesized from compound 3 (88 $\mathrm{mg}$, $0.35 \mathrm{mmol}$ ) in a manner analogous to that of compound 5 . Wt. $67 \mathrm{mg}, 82 \%$ Yield. $\mathrm{mp} 182-184^{\circ} \mathrm{C} ;{ }^{1} \mathrm{H}$ NMR (DMSO-d $\mathrm{d}_{6}$ ) $\delta 0.62$ (t, $\left.2 \mathrm{H}, \mathrm{BCH}_{2}\right), 1.22-1.35\left(\mathrm{~m}, 2 \mathrm{H}, \mathrm{BCH}_{2} \mathrm{CH}_{2}\right), 1.70-1.82(\mathrm{~m}, 2 \mathrm{H}$, $\left.\mathrm{CH}_{2} \mathrm{CH}_{2} \mathrm{~N}\right), 4.11\left(\mathrm{t}, 2 \mathrm{H}, \mathrm{CH}_{2} \mathrm{CH}_{2} \mathrm{~N}\right), 7.39\left[\mathrm{~s}, 2 \mathrm{H}, \mathrm{B}-(\mathrm{OH})_{2}\right], 8.02$ (s, $1 \mathrm{H}, \mathrm{H}-\mathrm{C} 8$ purine), $8.07(\mathrm{~s}, 1 \mathrm{H}, \mathrm{H}-\mathrm{C} 2$ purine), $12.25(\mathrm{~s}, 1 \mathrm{H}$, $\mathrm{H}-\mathrm{N} 3$ purine). ESMS calcd. for $\mathrm{C}_{9} \mathrm{H}_{13} \mathrm{O}_{3} \mathrm{~N}_{4} \mathrm{~B}$ 236.11 [MH] ${ }^{+}$, found 236.10 .

\section{2,6-Dichloro-9-(4-dihydroxyborylbutyl)purine 7}

This analogue was synthesized in a similar manner as outlined for compound 2 using 2,6-dichloropurine $(0.25 \mathrm{~g}, 1.30 \mathrm{mmol})$, 4-bromobutyl boronic acid $(0.24 \mathrm{~g}, 1.30 \mathrm{mmol})$, and $\mathrm{K}_{2} \mathrm{CO}_{3}$ (0.27 g, $1.98 \mathrm{mmol})$. Wt. $180 \mathrm{mg}, 48 \%$ Yield. $\mathrm{mp} 121-124^{\circ} \mathrm{C}$; ${ }^{1} \mathrm{H}$ NMR (DMSO- $\left.\mathrm{d}_{6}\right) \delta 0.61\left(\mathrm{t}, 2 \mathrm{H}, \mathrm{BCH}_{2}\right), 1.25-1.35(\mathrm{~m}, 2 \mathrm{H}$, $\left.\mathrm{BCH}_{2} \mathrm{CH}_{2}\right), 1.75-1.85\left(\mathrm{~m}, 2 \mathrm{H}, \mathrm{CH}_{2} \mathrm{CH}_{2} \mathrm{~N}\right), 4.23(\mathrm{t}, 2 \mathrm{H}$, $\left.\mathrm{CH}_{2} \mathrm{CH}_{2} \mathrm{~N}\right), 7.41\left[\mathrm{~s}, 2 \mathrm{H}, \mathrm{B}-(\mathrm{OH})_{2}\right], 8.75$ (s, $1 \mathrm{H}, \mathrm{H}-\mathrm{C} 8$ purine) ESMS calcd. for $\mathrm{C}_{9} \mathrm{H}_{11} \mathrm{O}_{2} \mathrm{~N}_{4} \mathrm{BCl}_{2} 288.93[\mathrm{MH}]^{+}$, found 289.10 .

\section{6-Chloro-9-[4-(1,3-propyldioxaborylbutyl)]purine 8}

Compound 3 (70 mg, $0.28 \mathrm{mmol}$ ) and 1,3-propanediol (22 mg, $0.28 \mathrm{mmol})$ were dissolved in THF $(10 \mathrm{ml})$ and stirred at room temperature overnight. The solvent was evaporated with a stream of nitrogen, and the crude product dissolved in a mixture of hexanes and $\mathrm{Et}_{2} \mathrm{O}$ (95:5). Undissolved solid was discarded, and pure product $(60 \mathrm{mg})$ was obtained after evaporation of solvent. Wt. $60 \mathrm{mg}, 74 \%$ Yield. $\mathrm{mp} 85-87^{\circ} \mathrm{C} ;{ }^{1} \mathrm{H}$ NMR (DMSO-d 6 ) $\delta 0.62\left(\mathrm{t}, 2 \mathrm{H}, \mathrm{BCH}_{2}\right), 1.22-1.35\left(\mathrm{~m}, 2 \mathrm{H}, \mathrm{BCH}_{2} \mathrm{CH}_{2}\right)$, 1.80-1.90 (m, 4H, $\left.\mathrm{CH}_{2} \mathrm{CH}_{2} \mathrm{~N}, \mathrm{OCH}_{2} \mathrm{CH}_{2} \mathrm{CH}_{2} \mathrm{O}\right), 3.82-3.95(\mathrm{~m}$, $4 \mathrm{H}, \mathrm{OCH}_{2} \mathrm{CH}_{2} \mathrm{CH}_{2} \mathrm{O}$ ), 4.29 (t, $2 \mathrm{H}, \mathrm{CH}_{2} \mathrm{CH}_{2} \mathrm{~N}$ ), 8.69 (s, $1 \mathrm{H}, \mathrm{H}-$ $\mathrm{C} 8$ purine), 8.81 (s, $1 \mathrm{H}, \mathrm{H}-\mathrm{C} 2$ purine). ESMS calcd. for $\mathrm{C}_{12} \mathrm{H}_{16} \mathrm{O}_{2} \mathrm{~N}_{4} \mathrm{BCl} 295.10[\mathrm{MH}]^{+}$, found 295.10.

\section{Materials and Experimental Procedures: Virology}

\section{Virus syncytial plaque assay and effective concentration $_{50}\left(E C_{50}\right)$ determinations.}

A monolayer of CEM-SS cells (T-lymphocytes) was prepared by dispensing 50000 cells per $50 \mu \mathrm{l}$ of RPMI- 1640 medium without serum to each poly-L-lysine treated well in a 96 -well plate. The cell monolayer formed after $30 \mathrm{~min}$ incubation at $37^{\circ} \mathrm{C}$ was inoculated with 30-60 plaque forming units of HIV-1 diluted in RPMI-1640 growth medium. After 90 min of virus adsorption, the infected cell monolayers were overlaid with $100 \mu$ growth medium supplemented with serial log or 0.5 log dilutions of test compound. The highest concentration of test compound was always 2-fold or more below the $\mathrm{IC}_{50}$ for cell toxicity. All plates were incubated at $37^{\circ} \mathrm{C}$ in a humidified atmosphere containing $5 \% \mathrm{CO}_{2}$ and $95 \%$ air. After 3 days incubation, a second overlay of growth medium supplemented with test or control compound was added and incubation at $37^{\circ} \mathrm{C}$ was continued for an additional 2 days (total of 5 days). Plaques were counted with the aid of a $10 \mathrm{X}$ gridded ocular lens and light microscope. The $\mathrm{EC}_{50}$ for anti-HIV-1 activity was calculated from computer program analysis of the antiviral data. If the $\mathrm{EC}_{50}$ for control compounds was not within $30 \%$ of expected values, the assay was considered invalid and repeated.

\section{Cytotoxicity assay with the SV-28 tumour cell line}

Preliminary biological screening for antitumour activity was done with the SV-28 cell line. SV-28 cells are baby hamster kidney cells transformed by the oncogenic simian virus SV -40 . Cells were grown in flasks with $25 \mathrm{~cm}^{2}$ growth area in MEM medium with $5 \%$ foetal calf serum. Immediately before use, $2 \mathrm{mM}$ of glutamine was added to the medium. The $\mathrm{pH}$ of the medium was adjusted from slightly basic to slightly acidic by adding $0.8 \%(\mathrm{v} / \mathrm{v})$ of $2 \mathrm{~N} \mathrm{HCl}$. Cells were transferred by washing with phosphate buffered saline (PBS) and incubated in $0.02 \%$ EDTA in PBS for 3 min to remove the cells from the flask surface. An appropriate number of cells were added to fresh medium such that the seeding density was $3 \times 10^{3}$ cells $\mathrm{cm}^{-2}$. After $\approx 24 \mathrm{~h}$, the test compound was added at different concentrations $(10,20,50 \mu \mathrm{M})$, and cells were incubated for another $48 \mathrm{~h}$ to allow three doublings according to control cells. At the end of $48 \mathrm{~h}$, cells were washed with $5 \mathrm{ml}$ of PBS and incubated with $2 \mathrm{ml}$ of $0.02 \%$ EDTA. The cells were loosened by tapping the flask and then were transferred to a test tube with $0.5 \mathrm{ml}$ of $5 \mathrm{mM} \mathrm{CaCl}_{2}$ in $0.9 \%$ saline. The cells were counted with a haemocytometer. Each compound was tested at least two times on separate occasions, and reproducible results were 
obtained. The $\mathrm{IC}_{50}$ value is the concentration of the test compound that reduced the cell count to $50 \%$ compared with the control culture. For compounds showing cytotoxicity, the experiments were repeated three times to determine the standard deviation.

\section{Anti-herpes plaque reduction assay}

Confluent monolayers of Vero cells in $9.6 \mathrm{~cm}^{2}$ plastic wells were inoculated with HSV-1 (KOS) in $0.5 \mathrm{ml}$ of RPMI-1640 medium supplemented with $5 \%$ calf serum. After $30 \mathrm{~min}$ of adsorption at $37^{\circ} \mathrm{C}$, the medium was replaced with a drug overlay, which contained $2.5 \mathrm{ml}$ RPMI-1640, $0.8 \%$ carboxymethycellulose, and $0.5 \%$ calf serum with test compounds at various concentrations $(10,20,50,100 \mu \mathrm{M})$. Each concentration was done in triplicate. After a 2 day incubation, the cells were fixed and stained with trypan blue. The number of plaques were counted, and the concentration that reduced the plaque count by $50 \%$ relative to untreated control was determined as the $\mathrm{EC}_{50}$ value. The $\mathrm{EC}_{50}$ value for aciclovir in the assay system was $1.5 \mu \mathrm{M}$ as reported previously (Bastow et al., 1983). Aciclovir at $50 \mu \mathrm{M}$, used as the positive control in the experiment, completely eliminated HSV plaque formation.

\section{Acknowledgements}

This work was supported in part by the Pardee Foundation.

\section{References}

Barnard, D.L., Huffman, J.H., Sidwell, R.W., and Reist, E.J. (1993) Selective inhibition of cytomegaloviruses by 9- (3'ethylphosphono-1'-hydroxymethyl-1'-propyloxymethyl)guanine. Antiviral Res 22: 77-89.

Bastow, K.F., Derse, D.D., and Cheng, Y.C. (1983) Susceptibility of phosphonoformic acid-resistant herpes simplex virus variants to arabinosylnucleosides and aphidicolin. Antimicrob Agents Chemother 23: 914-917.

Brown, H.C., and Gupta, S.K. (1971) 1 (3): 2-Benzodioxaborole, a convenient monofunctional hydroborating agent. A simple new synthesis of alkaneboronic esters and acids from olefins via hydroboration. J Am Chem Soc 93: 1816-1818.

Carter, D.B., Ross, D.A., Ishaq, K.S., Suarez, G.M., and Chae, C.B. (1977) The inhibition of rat liver chromatin protease by congeners of the phenylboronic acids. Biochim Biophys Acta 484: 103-108.

Chen, X., Bartolotti, L., Ishaq, K., and Tropsha, A. (1994) Molecular simulation of alkyl boronic acids: Molecular mechanics and solvation free energy calculations. J Comp Chem 15: 333-345.
Crumpton, S.C., Goz, B., and Ishaq, K.S. (1988) Novel lipid analogs with cytostatic and cytocidal activity. Anticancer Res 8: $1361-1366$.

De Clercq, E. (1995) Toward improved anti-HIV chemotherapy: Therapeutic strategies for intervention with HIV infections. $J$ Med Chem 38: 2491-2517.

Goralski, C., Singaram, B., and Brown, H.C. (1987) Hydroboration, 81. Synthesis of 2-(dialkylamino)boronic esters and acids via hydroboration of enamines. A convenient preparation of $\beta$-dialkylamino alcohols. J Org Chem 52: 4014-4019.

Goz, B., Ganguli, C., Troconis, M., Wyrick, S., Ishaq, K. S., and Katzenellenbogen, J. A. (1986) Compounds that inhibit chymotrypsin and cell replication. Biochem Pharmacol 35: 3587-3591.

Harnden, M.R., Jarvest, R.L., Bacon, T.H., and Boyd, M.R. (1987) Synthesis and antiviral activity of 9-[4-hydroxy-3(hydroxymethyl)but-1-yl]purines. $J$ Med Chem 30: 1636-1642.

Kinder, D.H., Frank, S. K, and Ames, M.M. (1990) Analogues of carbamyl aspartate as inhibitors of dihydroorotase: preparation of boronic acid transition-state analogues and a zinc chelator carbamylhomocystein. J Med Chem 33: 819-823.

Kucera, L.S., Iyer, N., Leake, E., Raben, A., Modest, E.J., Daniel, L.W., and Piantadosi, C. (1990) Novel membraneinteractive ether lipid analogs that inhibit infectious HIV-1 production and induce defective virus formation. AIDS Research and Human Retroviruses 6: 491-501.

Lee, K.H., Wu, Y.S., and Hall, I.H. (1977) Antitumor agents. 25. Synthesis and antitumor activity of uracil and thymine $\alpha$ methylene- $\delta$-lactones \& related derivatives. $J$ Med Chem 20: $911-915$.

Lesnikowski, Z. J., and Schinazi, R. F. (1993) Carboranyl oligonucleotides. 1 . Synthesis of thymidine $\left(3^{\prime}, 5^{\prime}\right)$ thymidine (o-carboran-1-ylmethyl)phosphonate. $J$ Org Chem 58: 6531-6534.

Philip, M., and Bender, M.L. (1971) Inhibition of serine protease by arylboronic acid. Proc Natl Acad Sci USA 68: 478-480.

Piantadosi, C., Marasco, Jr., C.J., Morris-Natschke, S.L., Meyer, K.L., Gumus, F., Surles, J.R., Ishaq, K.S., Kucera, L.S., lyer, N., Wallen, C.A., Piantadosi, S., and Modest, E.J. (1991) Synthesis and evaluation of novel ether lipid nucleoside conjugates for anti-HIV-1 activity. $J$ Med Chem 34: $1408-1414$.

Schaeffer, H.J., Beauchamp, L., de Miranda, P., Elion, G.B., Bauer, D.J., and Collins, P. (1978) 9-(2-Hydroxyethoxymethyl)guanine activity against viruses of the herpes group. Nature (London) 272: 583-585.

Schinazi, R.F., and Prusoff, W.H. (1985) Synthesis of 5- (dihydroxyboryl)-2'-deoxyuridine and related boron containing pyrimidines. J Org Chem 50: 841-847.

Vandendriessche, F., Snoeck, R., Janssen, G., Hoogmartens, J., Van Aerschot, A., De Clercq, E., and Herdewijn, P. (1992) Synthesis and antiviral activity of acyclic nucleosides with a 3 (S), 5-dihydroxypentyl or 4 (R)-methoxy-3 (S), 5dihydroxypentyl side chain. J Med Chem 35: 1458-1465. 